\title{
The positive impacts of ecotourism in protected areas
}

\author{
P. Lanier \\ Friends of Sustainable Tourism International, USA
}

\begin{abstract}
Ecotourism is a topic that has been rapidly gaining interest globally in the last decade. Is ecotourism a viable means to increase economic development while protecting the environment, or is it an unrealistic ideal that leads to overdevelopment, pollution, and the introduction of non-native species to fragile ecosystems? This paper presents four documented case studies which serve as examples of successful protection of tourist areas, and that ecotourism, when sufficiently planned and properly managed, does generate positive impacts. A detailed review of Ecoventura in the Galapagos, Lapa Rios in Costa Rica, Camp Denali in Alaska, and Guludo Lodge in Mozambique illustrate the viability of ecotourism in generating economic development, advancing the interests of the environment, promoting cultural diversity, and encouraging community involvement and education.
\end{abstract}

Keywords: ecotourism, responsible tourism, environmental conservation, economic development.

\section{Introduction}

Tourism is accounting for an increasing portion of the world's economy. According to the World Travel and Tourism Council, in 2011 alone, travel and tourism made up 9\% of GDP, employed 250 million around the world, and boasted a profit of 6 trillion USD [1]. As such a significant component of economic activity, travel and tourism have the potential to make a significant impact on the world.

Ecotourism, as defined by IUCN, is "environmentally responsible travel and visitation to relatively undisturbed natural areas, in order to enjoy and appreciate nature (and any accompanying cultural features - both past and present) that 
promotes conservation, has low visitor impact, and provides for beneficially active socio-economic involvement of local populations" [2]. As such, ecotourism has three pillars: sustainable business practices, community development and environmental stewardship.

Sustainable business practices are the practical means of minimizing an enterprise's environmental impacts and maximizing its self-sufficiency, which includes everything from building material selection to water usage. Community development entails the social, cultural and economic effects that the business and its visitors have on the local inhabitants. Not only should local culture, traditions and values always be respected while running a business, but there should also be a commitment to supporting and strengthening the local community. Environmental stewardship is comprised of the initiatives and programs to protect and conserve the surrounding natural environment.

The following paper will attempt to demonstrate that ecotourism is an effective way for businesses in tourism destinations to have a positive impact on their host communities and natural environment through four distinct case studies: Ecoventura in the Galapagos, Lapa Rios in Costa Rica, Camp Denali in Alaska, and Guludo Lodge in Mozambique.

\section{Ecoventura}

Giving back while providing intense, inspiring, hands-on wildlife experiences The Galapagos Islands, home to an abundance of exotic vegetation and animal life, represent one of Earth's most precious and unique ecosystems. In 1959, 100 years after the publication of Darwin's On the Origin of Species, Ecuador declared 97 percent of the Galapagos' overall landmass to be a national park. In 2001, the nation also established the marine reserve of Galapagos. More importantly, in 2007, UNESCO declared the Galapagos Islands an at-risk World Heritage Site. Although the Islands were removed from the list in 2010, conservationists feel it happened too soon, as the Islands are still very much at risk due to illegal fishing, unsustainable tourism, illegal migration and population growth, and the unwelcome introduction of non-native species.

\subsection{Offering authentic, intimate, green voyages since 1990}

Ecoventura Cruises, a family owned expedition cruise line based in Guayaquil, Ecuador, seeks to make a difference. The company has been protecting and touring the Galapagos Islands since 1990, enabling thousands of travellers to experience the area's natural beauty [3]. The company's goal is to provide guests with authentic experiences in intimate groups and safe, memorable voyages. Ecoventura began focusing seriously on "greening" its Galapagos tours in 1999 by re-evaluating operational procedures and equipment - a move that enabled the company to become the leader in ecotourism in the Galapagos Islands. 


\subsection{Investing in green: from a hybrid yacht to knowledgeable, local crews}

Since those first efforts, Ecoventura has invested more than half a million dollars to refurbish its company-owned fleet of private vessels to meet tough ecological standards. The company owns four expedition vessels; three identical first-class, 20-passenger yachts named Eric, Flamingo, and Letty; and a 16-passenger luxury dive liveaboard named Galapagos Sky. In keeping with the idea of local sustainability, each luxury vessel was custom-built in Ecuador. Eric, one the first-class yachts, boasts 40 solar panels and two wind generators, making it the first hybrid, carbon offset yacht in the Galapagos Islands.

Ecoventura also invests in its crew. Knowledgeable, friendly captains, often former members of the Ecuadorian Navy or Merchant Marine, lead expeditions, while local, onboard naturalists who speak fluent English educate guests about the Islands and its treasures. Most members of Ecoventura's crew have worked with the company since its founding; they are a united group, like a family, committed to doing everything possible to ensure guests enjoy a comfortable, memorable stay and return to their homes wiser about nature and the importance of conservation.

\subsection{Inviting guests to fully experience the Galapagos' natural environment}

Ecoventura aims not only to educate; it wants to please its passengers as well by offering intimate groups the most mind boggling, inspiring, hands-on wildlife experiences possible in the Galapagos Islands. Guests are treated to a host of memorable, eco-friendly activities, including hiking along volcanic formations, viewing nesting sea birds, visiting remote beaches peppered with sea lions, snorkelling with penguins and sharks, kayaking in secluded coves, and rafting in zodiacs to explore the surrounding wildlife. The company offers guided nature walks twice daily, led by naturalists trained to provide the ultimate intellectual and wilderness experience. While on their own, guests might choose to swim along the glorious beaches, or snorkel in deep water coves. Experienced scuba divers can explore the waters along Wolf Island and Darwin Island, two of the northernmost islands in the Galapagos archipelago, from the 16-passenger dive boat, the Galapagos Sky, which promises divers an amazing liveaboard experience.

Ecoventura keeps its guide to passenger ratio low to ensure guests return home with unforgettable memories. At one guide per ten passengers, the company offers the smallest ratio among Galapagos tour operators. Groups depart each Sunday, following one of two different routes through the Islands crossing the equator up to five times! The company also offers families with children under seventeen special Galapagos expeditions over school breaks which feature age-appropriate experiences and adventures that are just as memorable as are those for adults. 


\subsection{Giving back: partnering and investing in education and local communities}

Guests, although critical to the company's success, are not Ecoventura's sole focus; the company also strives to partner with and invest in its local communities. For instance, in 2000, Ecoventura volunteered to be the first cruise-line company certified by Smart Voyager, an ecological program developed by The Rainforest Alliance, an international non-profit that works primarily in the Americas [4]. In another example, Ecoventura partnered with the World Wildlife Fund to create the Galapagos Marine Biodiversity Fund. Through the fund, the company has raised more than $\$ 300,000$ for marine conservation efforts and to educate local children about the environment [5].

In 2012, Ecoventura also partnered with the Ecology Project International to allow local teens to participate in a field conservation course, which equips them with knowledge and hands-on environmental experiences in the Galapagos Islands [6]. The company has also supported the Alejandro Alvear School for at least a decade by providing salaries for teachers, as well as physical therapists for hearing-impaired adults and children with physical disabilities [7]. To involve guests in its sustainability efforts, Ecoventura partners with "Pack for a Purpose", a program that allows passengers to bring supplies needed by local schools.

From vessels to crews to guests to communities, Ecoventura is a company worth supporting and emulating, as it takes its commitment to conservation, preservation, and sustainability seriously.

\section{Lapa Rios}

A "five-leaf," tropical beach resort protecting the culture, the rainforest and rare, native species

The Lapa Rios Ecolodge and Nature Reserve, next to the Pacific Ocean in southwestern Costa Rica, sits on the lavishly green Osa Peninsula. The Osa Peninsula, filled with magnificent waterfalls and beautiful white beaches, is home to 2.5 percent of the world's biodiversity and serves as a wildlife passage or connection for rare Costa Rican species struggling to survive harsh developmental conditions in their natural habitat. The Osa Peninsula is also home to the Corcovado National Park, a special sanctuary to various rare and endangered species, such as pumas, scarlet macaws, and the harpy eagle. While the ecolodge offers respite to guests in search of a Costa Rican beach and rainforest experience, the nature reserve offers a natural buffer for the national park and a home to many rare species native to the region.

\subsection{Meeting the natural treasures of the Osa Peninsula, including rare wildlife and trees}

For instance, the Osa Peninsula is the jaguar's last refuge in Central America, while the reserve itself is home to 80 percent of the total population of the 
sangrillo colorado tree, one of 37 species of tree heading toward extinction [8]. Guests visiting the ecolodge and reserve may hear the chatter, whoops, and screeches of four native species of Costa Rican monkey - the squirrel monkey, white-faced capuchin, mantled howler, and the spider monkey - and spot other intriguing native creatures as well, such as the poison dart frog, the silky anteater, and the three-toothed sloth. Bird lovers visiting the reserve enjoy the challenge of identifying more than 300 bird species who call the reserve home, including the toucan and the reserve's beautiful namesake, the scarlet macaw.

\subsection{Ensuring permanent conservation for a "River of Scarlet Macaws"}

The Lapa Rios Ecolodge and the Lapa Rios Nature Reserve take their names from the scarlet macaw, or known simply as "lapa" in Costa Rica. It's reported that when the owners of the 1000-acre nature reserve rainforest toured the landscape for the first time, a 'river of scarlet macaws' flew overhead. Perhaps considering the flight serendipitous, the owners named this unique part of the rainforest "Lapa Rios," or "River of Scarlet Macaws".

The owners of Lapa Rios also believed that, in a time of overly zealous development, the treasures of their land needed preservation. With that in mind, they generously signed a conservation easement, which resulted in the permanent protection of the 1000 acres of tropical rainforest. The agreement also created a binding partnership between The Nature Conservancy and a leading Costa Rican land conservation organization, ensuring that Lapa Rios would be preserved indefinitely. The restrictions set forth in the agreement are intense, stating that, on Lapa Rios, there shall be no mining, forestry, hunting, and building of tourism facilities. The agreement does, however, allow for educational and scientific activities throughout the reserve.

For instance, the Lapa Rios Nature Reserve supports The Wildlife Conservation Program, which works to further develop the feline populations on the Osa Peninsula [9]. In this endeavor, researchers are using videos and cameras to capture wild felines in action, studying their moods, actions, and behaviors to help save and protect them and other highly endangered species. Lapa Rios, in addition to providing access to the land, also donates funds to the Program, enabling researchers to purchase equipment and continue their studies.

\subsection{Winning the five-leaf sustainability award: inviting guests to join the efforts}

Amidst the land and its wildlife is the Lapa Rios Ecolodge itself, where sustainability is a key value. In 2003, Lapa Rios became one of the first hotels in Costa Rica to receive a Certificate for Sustainable Tourism and to be awarded five-leaf status from the Costa Rica Tourism Board. This organization evaluates and rates a property's sustainability on a scale of one to five leaves, with five leaves being the highest achievement.

Although the public recognition is satisfying, even more so is being able to share the protected rainforest and its inhabitants with visiting guests. The ecolodge offers guided hiking and waterfall tours, during which visitors can 
experience Costa Rican wildlife in its natural habitat. Guests can kayak and surf, viewing a magnificent variety of colorful birds and fish, and contribute to preservation efforts by transplanting the primary seedling of a rare plant to an area of secondary growth. The ecolodge's well-informed local guides also steer guests in the direction of native craftspeople, spurring on and supporting the local economy. Costa Rica is renowned for its wildly colorful arts and crafts, including handmade musical instruments, oxen carts, pottery, and greeting cards and notepaper made from either bananas or coffee, both of which grow bountifully throughout the land.

\subsection{Giving back to the community and strengthening the conservation message}

Because ecotourism is about preserving and supporting native peoples as much as it is about environmental conservation, the owners of Lapa Rios are also involved in local educational efforts. For instance, they helped to create the Carbonera School, which has neighbored the Nature Reserve since the early 1990s, supporting elementary-school-aged children through donations, summer school programs, and educational outreaches related to the environment. Thanks to the success of the Carbonera School, the Osa Peninsula is now home to ten additional schools, all of which have been outfitted with dining rooms and school supplies. Overall, the educational programs supported and created by Lapa Rios's donors and researchers have positively affected more than 120 schools in the area.

Guests at Lapa Rios are invited to get involved in the ecolodge's education efforts as well by touring with the children of the Carbonera School community, a gesture that lingers long, strengthening Lapa Rios's conservation and preservation message that guests take back home.

\section{Camp Denali}

Bringing guests closer to the land without changing or disturbing the environment and wildlife

Camp Denali sits squarely in the heart of Denali National Park and Preserve, which spans six million acres. This eco-friendly and family-owned retreat delights visitors with clear views of Denali and the Alaska Range, Wonder Lake, and the 95 mile Denali Park Road.

Celia Hunter was one such visitor. After hiking and touring the surrounding landscape, she staked claim in 67 acres of an isolated, rocky ridge with a pond, acreage that would soon become Camp Denali. Celia, along with two like-minded explorers, Ginny and Morton Wood, founded Camp Denali to fulfil their life-long dream of owning a simple, rustic lodge where park visitors could stay and, according to the camp's website, "savor the vigor and freshness of this young country and absorb its spacious tranquility" [10]. 


\subsection{Conservation: a family tradition}

The three founders built the lodge using reclaimed supplies from the National Park Service, and ran it for 25 years before selling to Wallace and Jerryne Cole in 1975. Wallace and Jerryne Cole, always directly involved with lodge guests, ran Camp Denali for another 30 years before handing over the reins to their daughter and her husband in 2005. The new Cole owners, like their predecessors, consider caring for the lodge, its guests, and the surrounding landscape as part of the Cole family tradition.

So far, they've been successful: the camp remains remote, with a small amount of foot and vehicular traffic, allowing visitors to experience the natural Denali habitat as much as possible. Minimizing fuel and emissions on the grounds of Camp Denali also preserves a sense of peace and quiet for guests and employees.

\subsection{Renovating to improve conservation efforts}

The lodge itself is a true conservation effort, as its structure has changed very little due to various preservation efforts and the remote setting. The owners across generations have made few renovations to the foundation and lodging to maintain a remote and sustainable environment for guests. For instance, when the latest Coles added a new dining hall to the grounds of Camp Denali in 2008 to create more space, they also added more opportunities for energy conservation.

\subsection{Relying on solar and water for renewable energy}

Today, solar power and sustainable products power the dining hall, and water for the dining hall, bathrooms, and kitchen are preheated by the sun, which can raise the temperature to as much as 100 degrees Fahrenheit on a hot day. The solar power system, with photovoltaic panels collecting and storing the power of the sun all day long, also enables the lodge to use electrically powered generators as a backup, instead of as a prime power source. Camp Denali also gets energy from a hydroelectric system, added to the property in 1981 when the Coles gained control over access to free-flowing water on a mountainside adjacent to the lodge site.

\subsection{Conserving through everyday initiatives}

The Cole family is proud of their ability to reduce energy consumption through simple tasks, such as line-drying all laundry on the grounds, composting food and yard scraps, and using reusable products, such as cloth napkins, lunch bags, and water bottles. The camp also uses non-toxic, concentrated cleaning products to minimize its footprint more [11]. One of the major accomplishments of Camp Denali is that the few items that they do not completely consume or reuse are made of recyclable materials such as paper, aluminum, tin, cardboard, and recyclable plastic. 


\subsection{Sourcing food locally to reduce the footprint even more}

In the last decade, small-scale farms in Alaska have become increasingly successful in raising pork, elk, reindeer meat, and fish and shellfish - all common in Alaska. Raising animals in Alaska is a serious business, and Camp Denali is fortunate enough to receive some of its meat and sausages from Delta Meat and Sausage Company, a family business that raises its own cattle and pigs in addition to running a USDA-certified meat-processing operation.

Several small, local farms provide Camp Denali with basic food supplies, such as lettuce, greens, onions, potatoes, squash, carrots, and more. Camp Denali orders food and other needed culinary goods locally to further reduce its environmental footprint. Organic farmers in the area provide flowers, herbs, fruits, and vegetables to Camp Denali as well. Camp Denali is also known for its on-site greenhouse and outdoor, raised-bed, kitchen gardens.

\subsection{Working together to instil in guests a desire to respect and care for the environment}

In many ways on a daily basis, the owners and employees of Camp Denali act on a core belief that it's important for guests to experience both conserving and preserving the environment, as well as to experience nature and wildlife in as close to its natural state as possible. The overarching goal is that guests are changed when they return home; that they are equipped with a mindset that nature not be disregarded as background, and that each one of us are partners in creating a sustainable environment. To help further instil these values in guests, Camp Denali also offers engaging activities, such as learning adventures and hiking vacations, led by local naturalists, who guide guests into experiencing the park and its environment intellectually as well as leisurely with the hopes of changing attitudes.

\section{Guludo Beach Lodge}

A sustainable business and sister organization restoring hope and rebuilding communities

The Guludo Beach Lodge, a balmy tourist destination in Mozambique's Quirimbas National Park, began as a dream in the minds of Neal and Amy Carter-James. The pair visited the poverty-stricken area in 2002, envisioning a blend of tourism and philanthropy that could lift the veil of poverty that had long since settled over the people of Mozambique.

Today, Guludo Beach Lodge acts as an area resource by donating five percent of its profits to the Nema Foundation, a sister organization the Carter-Jameses created with the intention of supporting the local community and economy. The Nema Foundation cooperates with sixteen local communities near the Guludo Beach Lodge, creating projects that benefit the area economically and culturally. 


\subsection{Bringing help and hope where it is most needed}

The assistance is needed, as Guludo, although rich in beauty with its 7.5 mile palm-fringed beach, is situated in one of Mozambique's poorest areas. The life expectancy of local adults is only 38 years, and one in three children do not reach their fifth birthday [12]. Before the Carter-James came along, the community lacked guaranteed access to clean water, and the education system was almost non-existent since very few children attend school. People also lacked a sense of cultural identity, and had to rely on threatened and endangered resources. Without the help of outside hands, the people living in the Guludo area of Mozambique would not have had the ability to thrive or to cause change in their environment, both financial and natural.

\subsection{Restoring access to a land rich in beauty, wildlife, and culture}

The natural environment itself is worth respecting and saving. Quirimbas National Park, the largest marine-protected area in Africa and home to five species of turtles, calving humpback whales, grazing dugongs, and beautiful coral reefs, is an ideal setting for conservation and tourism. The park encompasses eleven islands of the Quirimbas Archipelago, which stretches north to bordering Tanzania. These tropical islands act as a vast reservoir of Africa's historical and cultural past, and illustrate the influences of the Arab and Portuguese cultures on the land as well.

Quirimbas National Park also encompasses land on the continent, protecting plentiful coastal forest inhabitants that once populated the East African coastline but have since moved inland: elephants, lions, leopards, crocodiles, and even wild dogs [13]. Historically, the country's decades-long civil war cut off the remote region now reserved for the park, leaving it a grey area in both Southern and East African field guides. Thanks to Guludo and other tourism and ecologic efforts, the park is blossoming and is rejoining society, opening its land where new species and treasures wait to be discovered.

\subsection{Achieving recognition and offering guests the best of Africa}

Northern Mozambique and Guludo are being noticed, having been called next travel hotspots with world class beaches and hotels. It's no wonder, as Northern Mozambique lays claim to the best beaches in Africa, pristine coral reefs, and a rich cultural heritage.

Guludo Beach Lodge invites guests to experience all that the locals have to offer, from land and nature to local gifts, foods, and customs. Guests can scuba dive, snorkel, visit Quirimbas National Park, visit Guludo village, partake in bush lookouts, and more. The lodge positions itself in the luxury class, offering guests anything and everything they need to enjoy a barefoot retreat complete with endless beach views and gentle sea breezes. 


\subsection{Shifting tourism gains to lift local peoples and communities}

Winner of several international awards, Guludo Beach Lodge is responsible for a significant influx of tourism to Mozambique year round. Tourism has deeply affected the area's surrounding local communities, which is exactly what the Carter-Jameses intended. The lodge inspires and fuels the local economy, while the Nema Foundation tackles the leading causes of poverty and the environmental problems that have for years stunted Mozambique's prosperity. [14] In that regard, Guludo Beach Lodge is an example of a successful, sustainable business with a sister organization that supports community development projects and highly impactful conservation efforts.

\subsection{Measuring results with clean water, meals, mosquito nets, and education}

The Carter-James's success is supported by numbers. Since Guludo Beach Lodge opened, more than 20,000 people have gained access to clean water, and more than 900 malnourished children receive education and a school meal each day. Nearly one hundred thirty young scholars have received a secondary education. The Nema Foundation has also been responsible for providing 9,500 mosquito nets, building two primary schools, and educating local families about nutrition, malaria, HIV, hygiene, and sanitation. The effects of Guludo extend into the local business community as well, with the lodge supporting more than one hundred fifty local suppliers, employing seventy staff members, and enabling eight local businesses to sell products directly to lodge guests.

\subsection{Combining green efforts with tourism and philanthropy for eco-success}

Today, a new and growing sense of optimism is alive in the communities surrounding Guludo, which prospers by drawing tourists from near and far. With more tourism and profits, the more that Guludo could contribute to the Nema Foundation and to the local economy. From 2009 to 2012, a time of great struggle for many businesses in the tourism industry, Guludo Beach Lodge experienced exceptional growth. The Carter-Jameses plan to continue to expand the lodge's and the foundation's efforts to bring more prosperity and hope and environmental conservation to the region in the years to come.

\section{Conclusion}

Through these case studies of eco-resorts and their best practices, we have endeavored to show how conscious, careful development, while certainly not a panacea, especially when transit to these far-flung destinations burns fossil fuels, is nonetheless the best hope that the ever-expanding reach of world tourism will have positive effects on the environment and the local people. With the environment uppermost in their minds, ecotourism enables travelers to learn about sustainable practices and serve as examples to their peers.

While empirical data is just now emerging that "deep green" carefully conceived and executed ecotourism provides conservation benefits, it is 
imminently apparent that hosting adventurous travellers in fragile areas provides a positive alternative to the destruction of habitat and decimation of animal and forest resources through other sources of income- logging, mining, overfishing and endangered animal sales- available to communities struggling to survive and maintain their cultural heritage. Employing and supporting education for community stakeholders is one of the most obvious as well as long-lasting results.

As environmental visionary Paul Hawken said in his speech to the San Francisco Commonwealth Club in 1992, "Business is the only mechanism on the planet today powerful enough to produce the changes necessary to reverse global environmental and social degradation" [15]. Eco-travel is a leading example of this principal at work today.

\section{References}

[1] World Travel \& Tourism Council, Benchmarking Travel \& Tourism, Americas Summary: How does Travel \& Tourism compare to other sectors? April, 2012.

[2] IUCN, Resolution CGR 1.67 'Ecotourism and Protected Area Conservation'. 1st World Conservation Congress: Montreal, 1996.

[3] Ecoventura, "Social and Environmental Responsibility". www.ecoventura. com/galapagos-sustainability/social-environmental-responsibility

[4] Ecoventura, "Smart Voyager Certification". www.ecoventura.com/ galapagos-sustainability/smart-voyager-certification

[5] Ecoventura, "Galapagos Marine Diversity Fun". www.ecoventura.com/ galapagos-sustainability/wwf-galapagos-marine-biodiversity-fund

[6] Ecoventura, "Ecology Project International". www.ecoventura.com/ galapagos-sustainability/ecology-project-international

[7] Ecoventura, "Pack with a Purpose". www.ecoventura.com/galapagossustainability/pack-purpose

[8] Lapa Rios, "Conservation at Lapa Rios". www.laparios.com/ conservation.html

[9] Lapa Rios, "Join a Wildcat Expedition". www.laparios.com/wildcat.html

[10] Camp Denali, "Our History" www.campdenali.com/live/page/our-history

[11] Camp Denali, "Sustainability" www.campdenali.com/live/page/ sustainable-practices

[12] Guludo Beach Lodge, "About Us” www.guludo.com/content/about-us

[13] Guludo Beach Lodge, "Quirimbas National Park" www.guludo. com/content/quirimbas-national-park

[14] Guludo Beach Lodge, "Guludo Beach Lodge" www.ecogo.org /th_gallery/guludo-beach-lodge

[15] Hawken, P., Speech to the Commonwealth Club, 1992, San Francisco, California. 